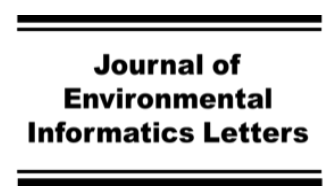

WWw.iseis.org/jeil

\title{
Feasibility of Saline Gradient Solar Ponds as Thermal Energy Sources in Saskatchewan, Canada
}

\author{
M. Ito ${ }^{1}$ and S. Azam ${ }^{*}$ \\ ${ }^{1}$ Environmental Systems Engineering, Faculty of Engineering and Applied Science University of Regina, 3737 Wascana Parkway, Regina, SK \\ S4S OA2, Canada
}

Received 14 January 2019; revised 25 May 2019; accepted 19 June 2019; published online 30 June 2019

\begin{abstract}
Advancement of renewable energy is critical for sustainable development. This paper evaluates the feasibility of saline gradient solar ponds (SGSP) as an alternative energy source for Saskatchewan, Canada. The main achievements include global appraisal of SGSP from theoretical and practical perspectives, assessment of salinity and climatic criteria for SGSP potential, understanding of heat transfer mechanisms affected by thermophysical properties, and numerical modeling to simulate transient heat diffusion in SGSP. Results indicated that Saskatchewan is ideal for thermal energy harvesting from saline water bodies because of high solar insolation (1100 to $1400 \mathrm{kWh} / \mathrm{m}^{2}$ ). The solar radiation in such systems is captured under a salt concentration gradient. Locally, ten potash tailings sites $(360 \mathrm{~g} / \mathrm{L}$ or $36 \%$ salt $)$ and two saline water lakes $(250 \mathrm{~g} / \mathrm{L}$ or $25 \%$ salt $)$ are potentially suitable for SGSP deployment. It was found that thermal conductivity increases with temperature but decreases with water salinity increase $(0.55$ to $0.675 \mathrm{~W} / \mathrm{mK})$ and the opposite is true for density $\left(1000\right.$ to $\left.1200 \mathrm{~kg} / \mathrm{m}^{3}\right)$. Similarly, specific heat capacity slightly increases with temperature and inversely correlates with salinity ( 3000 to $4200 \mathrm{~J} / \mathrm{kg} \mathrm{K}$ ). Furthermore, the heat diffusion model adequately simulated the temperature distribution for a typical SGSP in a potash tailings containment facility. For the investigated month of July (highest solar insolation), the temperatures increased from an initial value of at 20 to $52{ }^{\circ} \mathrm{C}$ at top to $37^{\circ} \mathrm{C}$ at bottom. A comprehensive risk assessment of this method is required to protect air, water, soil, and biota at specific sites.
\end{abstract}

Keywords: salinegradientsolar ponds, thermal energy, natural lakes, tailings ponds, heat diffusion

\section{Introduction}

The ever-growing demand for energy means that an increased amount of hydrocarbon fuels (such as oil, gas, and coal) will continue to be used in the foreseeable future (International Energy Agency, 2014) because of their abundance and ease of use. This is especially true for low-grade heat generation that is associated with a temperature increase of up to 50 ${ }^{\circ} \mathrm{C}$ above ambient conditions (Wang and Ma, 2015). To effecttively mitigate the adverse effects of hydrocarbon com-bustion on the atmosphere (such as $\mathrm{CO}_{2}$ emissions and green-house effects), there is an enhanced interest in exploring alternative energy options. Although high energy outputs can be achieved through photovoltaic solar panels and wind or water turbines (Jacobson and Delucchi, 2011), high capital and operational costs and intermittent availability are the main limitations of most of the emerging methods.

A saline gradient solar pond (SGSP) can provide an energy solution that is environmentally friendly (because of negligible emissions), cost effective (offering low initial and maintenance

* Corresponding author. Tel.: +1 306-337-2369; fax: +1 306-585-4855.

E-mail address: shahid.azam@uregina.ca (S. Azam).

ISSN: 2663-6859 print/2663-6867 online

(C) 2019 ISEIS All rights reserved. doi:10.3808/jeil.201900008 expenses), and socially acceptable (already operative in natural lakes). Such a system requires a shallow water body with appropriate quantities of dissolved salts and an adequate amount of solar radiation prevalent at the site. This thermal phenomenon was first reported in Lake Madoc (Romania) with bottom temperatures of up to $70{ }^{\circ} \mathrm{C}$ at $1.3 \mathrm{~m}$ depth (Kalecsinsky, 1902). Likewise, the mechanism has been shown to work under cold conditions such as Lake Vanda (Antarctica) that is covered with $3 \sim 4 \mathrm{~m}$ thick ice layer and exhibits $25{ }^{\circ} \mathrm{C}$ temperature at its deepest parts (Abdullah et al., 2017).

SGSP has been adapted in man-made systems such as tailings containment facilities (that is, ponds containing postextraction waste slurries) with appropriate chemical composition. Successful applications of SGSP have been reported for mineral production (Lesino and Saravia, 1991; Garrido et al., 2012; Montalà et al., 2019) and desalination processes (Lu et al., 2001; Garman and Muntasser, 2008; Saleh et al., 2011). More importantly, SGSP is applicable to potash solution mining for providing heat energy for on-site utilization. For example, Aimone-Martin and Martell (2000) developed such a system for mineral crystallization at a facility in New Mexico, USA (cold semi-arid climate) where a low relative humidity and an adequate cloud cover contribute to a high annual solar insolation of up to $1900 \mathrm{kWh} / \mathrm{m}^{2}$. Saskatchewan (Canada) is quite suitable for the deployment of this technology because it has 
natural saline lakes and potash tailings ponds with adequate salt concentrations $(25 \sim 360 \mathrm{~g} / \mathrm{L})$ and it receives an annual solar insolation between 1100 to $1400 \mathrm{kWh} / \mathrm{m}^{2}$ (Ito and Azam, 2018).

The main objective of this study was to evaluate the feasibility of SGSPs as a thermal energy sources in the area. First, the typical mechanism of SGSP is presented and the practical experience with this technology from around the globe is summarized. Second, the mean daily global insolation for $415 \mathrm{mu}-$ nicipalities was retrieved from the Photovoltaic Potential and Insolation Database (Natural Resources Canada, 2018) and converted to monthly and annual values to develop a temporal correlation. Third, a spatial relationship was developed using the Google Earth web application to obtain the global positions of the municipalities and the saline water bodies. Fourth, potential SGSP sites were identified for possible implementation of this method. Fifth, the effect of thermophysical properties on the heat transfer mechanism was established to identify appropriate methods and limits operative in such systems. Finally, a conceptual heat diffusion model was developed for a potash tailings containment facility as a typical candidate for SGSP in Saskatchewan.

\section{Literature Review}

\subsection{Theoretical Background}

SGSP facilities collect solar energy in the form of heat that can be used for industrial processes, electricity generation, and space heating (French et al., 1985; Akbarzadeh et al., 2005). Figure 1 shows the conceptual model for SGSP in terms of energy balance and profiles of salt concentration and temperature (Ormat Turbines Ltd., 1981; Busquets et al., 2012; Ito and Azam, 2018). Solar radiation is captured under the salt concen-tration profile (Halocline) when the following three zones are established within the water body: (i) upper convective zone (UCZ), water layer with insignificant salinity and ambient air temperature; (ii) non-convective zone (NCZ), water layer with gradually increasing salinity ( $0 \%$ to $25 \%$ by mass) and temperature; and (iii) lower convective zone (LCZ), brine layer ( $\geq 25 \%$ by mass) at higher temperatures.

Solar energy, entering into SGSP, is partially absorbed and transformed to thermal energy at the pond bottom. During this process, heat transfer in the NCZ (increasing salinity) is primarily governed by the diffusion phenomena through the Soret effect, that is, mass transfer of salt particles in the saline liquid results in heat transfer (Kim, 2013). Random Brownian motion at the molecular level takes place due to collisions under the thermal gradient to propagate heat in all directions (Guerrero et al., 2013). In contrast, the heat transfer mechanism in the UCZ (negligible constant salinity) and LCS (high constant salinity) is governed by diffusion and internal convection involving bulk fluid circulation due to temporal temperature fluctuations at the boundaries. Despite thermal effect, the fluid density difference imposed by the salt concentration difference largely suppresses global convection within the NCZ. Likewise, a stable salt concentration gradient allows solar radiation to reach to the LCZ and store heat even in the absence of sunlight (Gonzalez et al.,
2016).

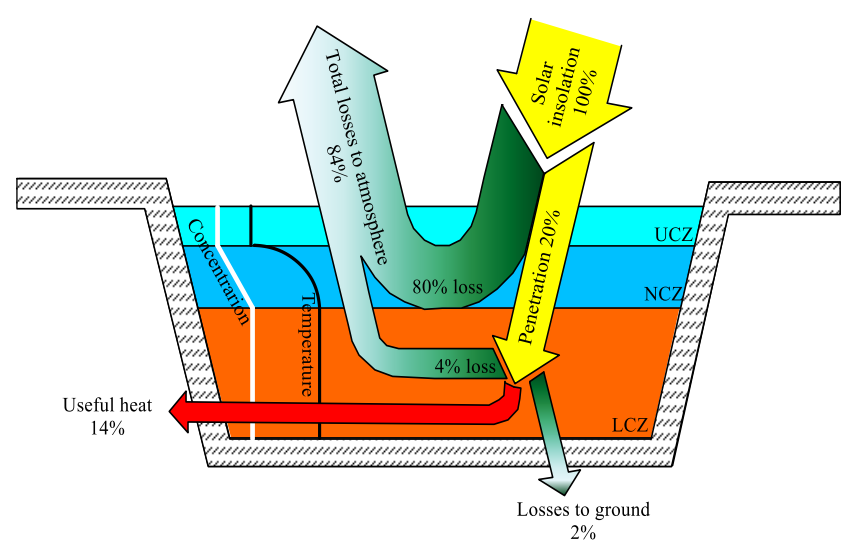

Figure 1. Schematic of saline gradient solar pond with estimated energy balance and profiles of salt concentration and temperature (After Ormat Turbines Ltd., 1981; Busquets et al., 2012; Ito and Azam, 2018)

\subsection{Practical Logistics}

Heat is generally extracted from the lower layers through one of the two mechanisms. The SGSP at El Paso (USA) utilizes an external heat exchanger system that requires pumping of brine from the top of the LCZ at steady velocity along with a returning brine flow post heat extraction ( $\mathrm{Lu}$ et al., 2004). In contrast, the SGSP at Pyramid Hill (Australia) uses an in-pond heat exchanger system at the bottom of the LCZ which requires a circulating heat transfer fluid in a closed cycle (Lablanc et al., 2011). Additionally, heat recovery can be improved using the following methods: gravity assisted heat collection system (Tundee et al., 2010); bottom polystyrene insulation system (Ganguly et al., 2018); plastic cover for evaporation prevention (Ruskowitz et al., 2014); and fiber-optic sensors for NCZ erosion detection (Sarabia et al., 2018).

Ormat Turbines Ltd. (1981) numerically modeled the energy balance for a hypothetical pond with $1.0 \mathrm{~km}^{2}$ surface area and $3.5 \%$ salt concentration (typical value for continental shelf seawater). The modeling indicated that part of the incoming solar insolation $(20 \%)$ penetrates to the NCZ while $80 \%$ is reflected back to the atmosphere. Upon further penetration to the LCZ, minor amounts of solar energy are lost to the atmosphere $(4 \%)$ and the ground $(2 \%)$. Despite a low thermal efficiency $(14 \%)$ of the pond, the entrapped thermal energy could warm up the LCZ to $65^{\circ} \mathrm{C}$ under sunny climates. Similar successful industrial applications have been reported from other parts of the globe. For example, reaching up to $90{ }^{\circ} \mathrm{C}$ in a flotation cell using an annual solar insolation of $1600 \mathrm{kWh} / \mathrm{m}^{2}$ in Granada, Spain (Alcaraz et al., 2018) and achieving an average air tem-perature of $40{ }^{\circ} \mathrm{C}$ utilizing an annual solar insolation of $1500 \mathrm{kWh} / \mathrm{m}^{2}$ in Victoria, Australia (Bawahab et al. 2019).

\subsection{Climatic Scoping}

Figure 2 provides the global distribution of SGSP projects. 


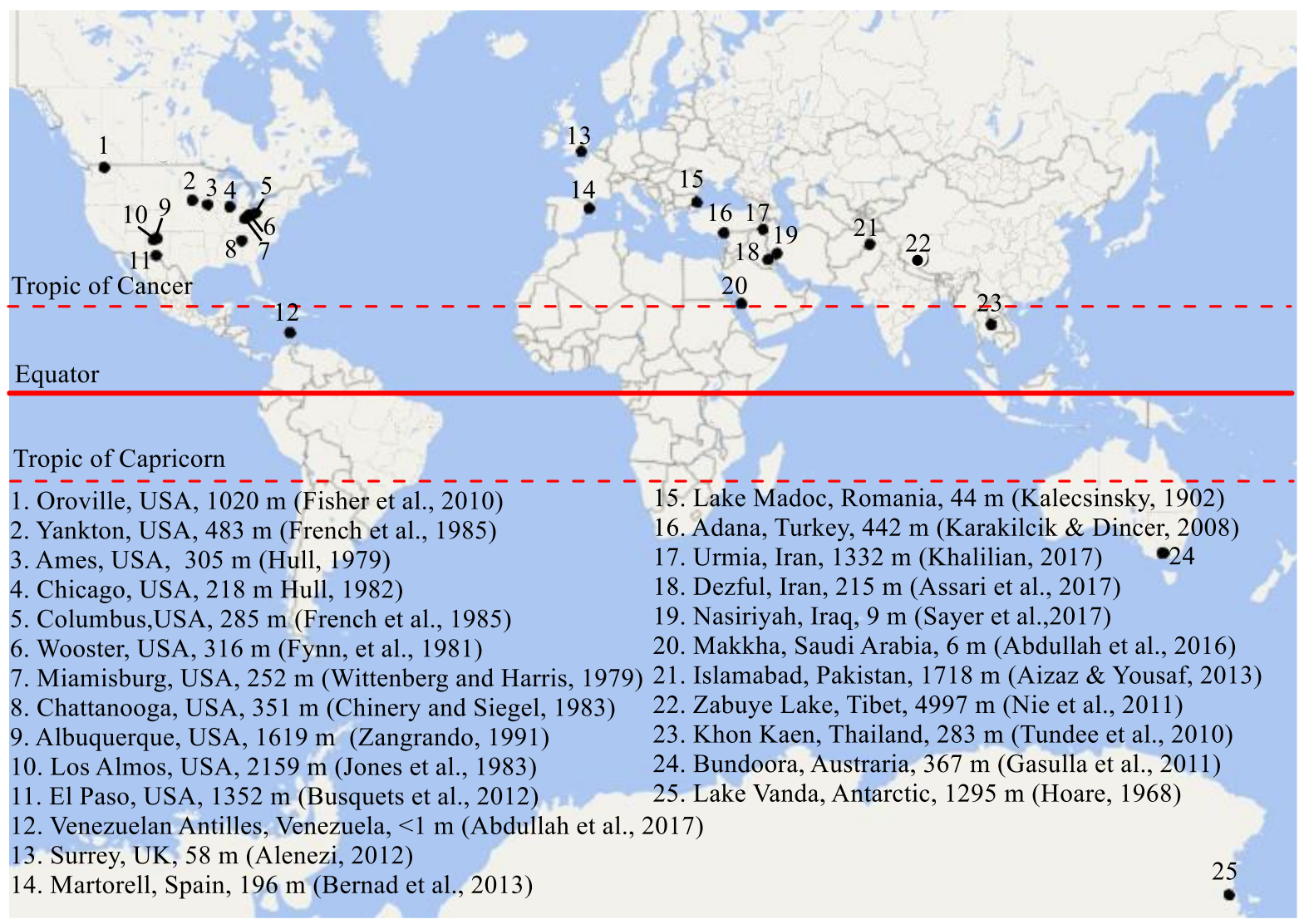

Figure 2. Global distribution of reported SGSP sites

Whereas such facilities can be developed across the globe, the majority of reported sites are located above the Tropic of Cancer $\left(23.5^{\circ} \mathrm{N}\right)$ at various elevations ranging from $6 \mathrm{~m}$ through $5000 \mathrm{~m}$ above mean sea level. In addition to latitude and altitude, the presence of adequate solar energy at a given site depends on local weather conditions. The influence of climatic factors on the efficiency of SGSP can be summarized as follows (Alenezi, 2012; Liu et al., 2015): (i) dilution of salts due to snowmelt improves solar penetration during spring-summer; (ii) turbidity due to rainfall and/or wind during summer-fall reduces solar penetration during summer; and (iii) snow cover offsets the low ambient air temperature during fall-winter.

Figure 3 plots the variation of mean annual solar insolation with respect to latitude such that the range is derived from the longitude. The data were obtained from the National Aeronautics and Space Administration of the United States of America (NASA Langley Research Center, 2018). The figure indicates two opposite trends, namely; an increase in solar insolation from the North Pole up to the Equator and a decrease from the Equator to the South Pole. The factors affecting the relatively larger range in solar insolation around equatorial regions are unknown. As expected, the reported SGSP sites were found to be within the range of variability. The actual value of solar insolation at a site depends on one or more of the following factors: (i) seasonal and daily weather variations; (ii) particulate matter and greenhouse gases in the atmosphere; and (iii) topographic features and elevation above mean sea level.

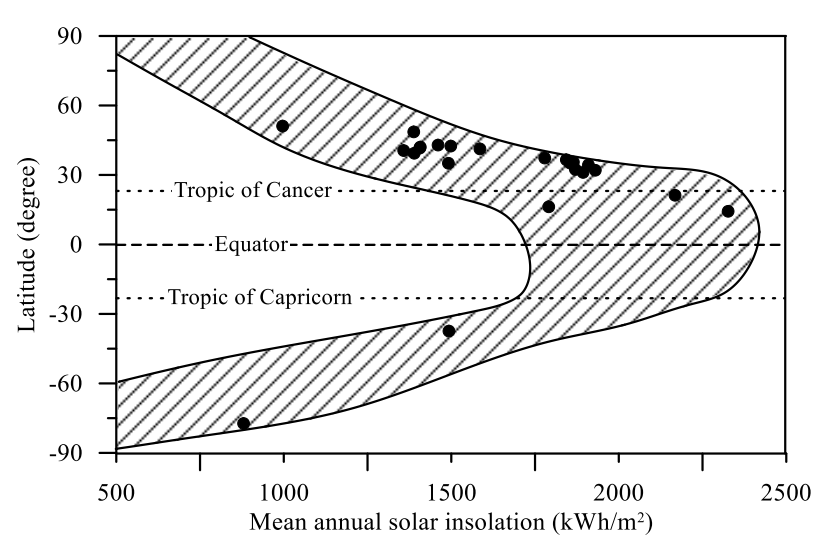

Figure 3. Global variation of solar insolation along with reported SGSP sites

Figure 4 gives the mean annual solar insolation in Canadian cities. The annual insolation ranges from $956 \mathrm{kWh} / \mathrm{m}^{2}$ in Iqaluit (Nunavut) to $1350 \mathrm{kWh} / \mathrm{m}^{2}$ in Regina (Saskatchewan). Cities in the Prairies (Regina, Calgary, and Winnipeg) generally rank higher and the annual insolation values in various locations cor- 
relate with the latitude $\left(\mathrm{R}^{2}=0.64\right)$. As mentioned earlier, latitude is not the only factor determining the annual insolation amount because locations of similar latitude are affected by seasonal weather and the site elevation (Nie et al., 2011). Nonetheless, French et al. (1985) concluded that SGSP is suitable for North American climate and that such facilities continuously produce heat required for domestic use in Ohio and industrial application in New Mexico.

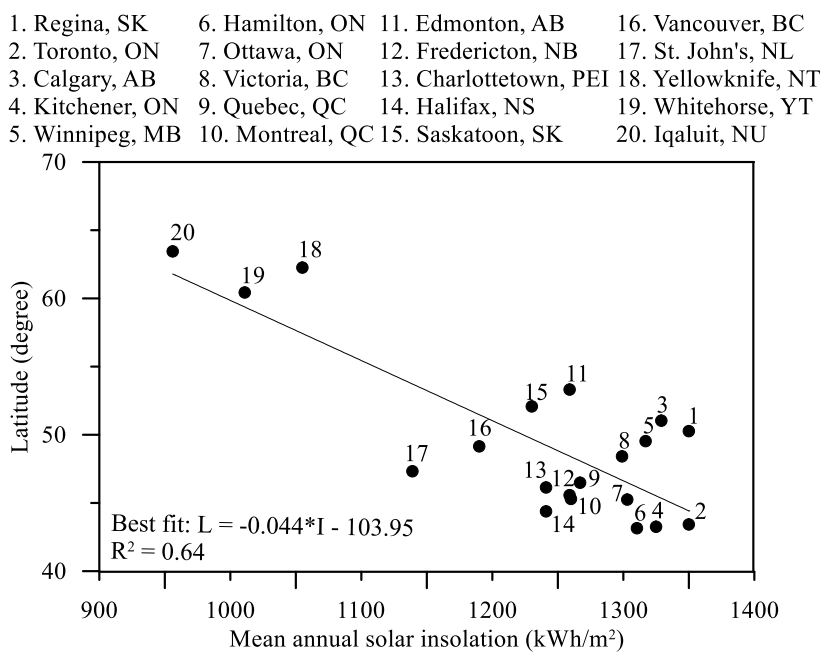

Figure 4. Mean annual solar insolation in Canadian cities

\section{Assessment of Criteria for SGSP Potential}

\subsection{Salinity Based Criteria}

Saskatchewan hosts 535 natural saline water lakes (up to $10 \mathrm{~km}^{2}$ and $5 \mathrm{~m}$ depth), which can be classified as follows: hypo-saline ( $3 \sim 20 \mathrm{~g} / \mathrm{L}$ concentration); meso-saline (20 $\sim 50$ $\mathrm{g} / \mathrm{L}$ concentration); and hyper-saline (> $50 \mathrm{~g} / \mathrm{L}$ concentration). Normally, moderate water salinity ponds are dominated by $\mathrm{Ca}^{2+}, \mathrm{Mg}^{2+}$, and $\mathrm{HCO}_{3}{ }^{-}$and higher water salinity ponds possess abundant $\mathrm{Na}^{+}$and $\mathrm{Cl}^{-}$(Hammer, 1986). These lakes were formed as a result of a deep collapse due to dissolution of Devonian evaporites (1000 $\mathrm{m}$ below surface) during the deglaciation period. High hydrostatic pressure exerted by excessive ground water recharge from melting glaciers burst the Tertiary and Quaternary sediments and fractures were developed. Transportation of saline water from below the Cretaceous aquifer was facilitated through these discontinuities in the bedrocks and formed saline lakes. Such conditions are prevalent across Central and Southern Saskatchewan (Christiansen, 1971). The total dissolved solids (TDS) for saline lakes ranges from $25 \mathrm{~g} / \mathrm{L}$ to $250 \mathrm{~g} / \mathrm{L}$ and these numbers are respectively equivalent to salt concentrations of 2.5 to $25 \%$ by mass (Bowman and Sachs, 2008).

Man-made saline water bodies (potash tailings ponds) result from wet mineral processing operations across Saskatchewan. According to Holter (1969), the above-mentioned Middle Devonian evaporites comprises of interbedded halite (sodium chloride, $\mathrm{NaCl}$ ) and sylvite (potassium chloride, $\mathrm{KCl}$ ).
The sylvite is extracted and the residual $\mathrm{NaCl}$-rich slimes are disposed of in designated containment areas $\left(1 \sim 4 \mathrm{~km}^{2}\right)$ at high slopes $\left(30 \sim 40^{\circ}\right)$ near the discharge points that gradually diminishes to form a brine pond at the toe of the hill (Tallin et al., 1990). The TDS for typical potash tailings storage facilities is $360 \mathrm{~g} / \mathrm{L}$ corresponding to $36 \%$ salt concentration by mass (Landine, 1993).

\subsection{Climate Based Criteria}

Figure 5 gives the monthly variabilities of average solar insolation in Saskatchewan. The monthly solar insolation periodically oscillates with an amplitude of $\pm 80 \mathrm{kWh} / \mathrm{m}^{2}$ (standard deviation) from the mean value of $110 \mathrm{kWh} / \mathrm{m}^{2}$ with extreme values ranging from as high as $190 \mathrm{kWh} / \mathrm{m}^{2}$ in July to as low as $30 \mathrm{kWh} / \mathrm{m}^{2}$ in December. This is due to seasonal changes in the instantaneous measurement of solar power per unit area (that is, irradiance is maximum in summer and minimum in winter for the northern hemisphere of the globe). Furthermore, the insolation variability within the summer months is negligible across Saskatchewan because the higher day length in the north is compensated by a low irradiance and vice versa. These results correlate well with the photovoltaic potential $(\mathrm{kWh} / \mathrm{kW})$ map calculated on the basis of solar insolation values (Pelland et al., 2006). This means that the entire province is suitable for a stable solar energy harvesting during summer.

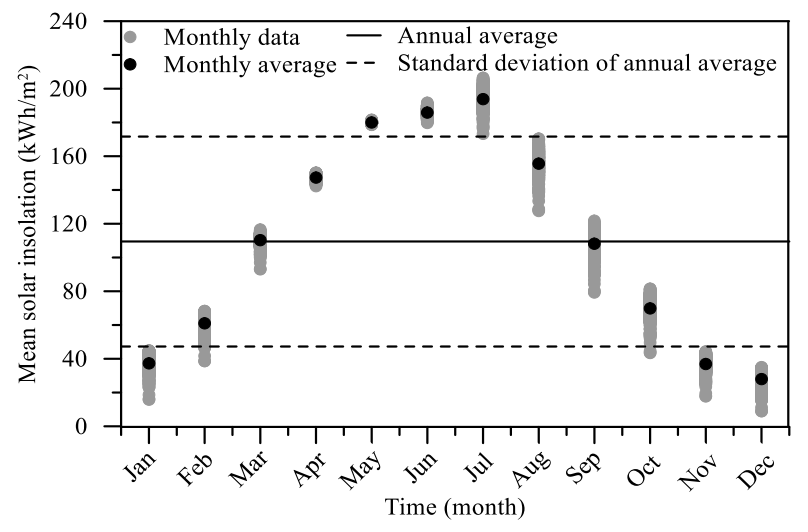

Figure 5. Monthly variation of solar insolation in Saskatchewan

Figure 6 illustrates the solar insolation map superimposed with saline water systems (10 potash mine sites and 10 saline water lakes) in Saskatchewan. These sites are located in southern Saskatchewan between the latitude $50^{\circ} 25^{\prime}$ and $52^{\circ} 70^{\prime}$. The seasonal variation (every three months period) of solar insolation throughout the year is color coded. As mentioned above, the composition of saline water bodies indicated abundant $\mathrm{NaCl}$ and minor amounts of $\mathrm{KCl}$. Finally, the investigated potash tailings containment facilities with $36 \%$ salinity and at least two saline lakes with $25 \%$ salinity (Chaplin and Ingebrigt) are suitable SGSP candidates receiving $1300 \mathrm{kWh} / \mathrm{m}^{2}$ of solar insolation annually. The latter data for these sites falls within the range for SGSP selection, as described earlier in Figure 3 (1100 and $1400 \mathrm{kWh} / \mathrm{m}^{2}$ ). 


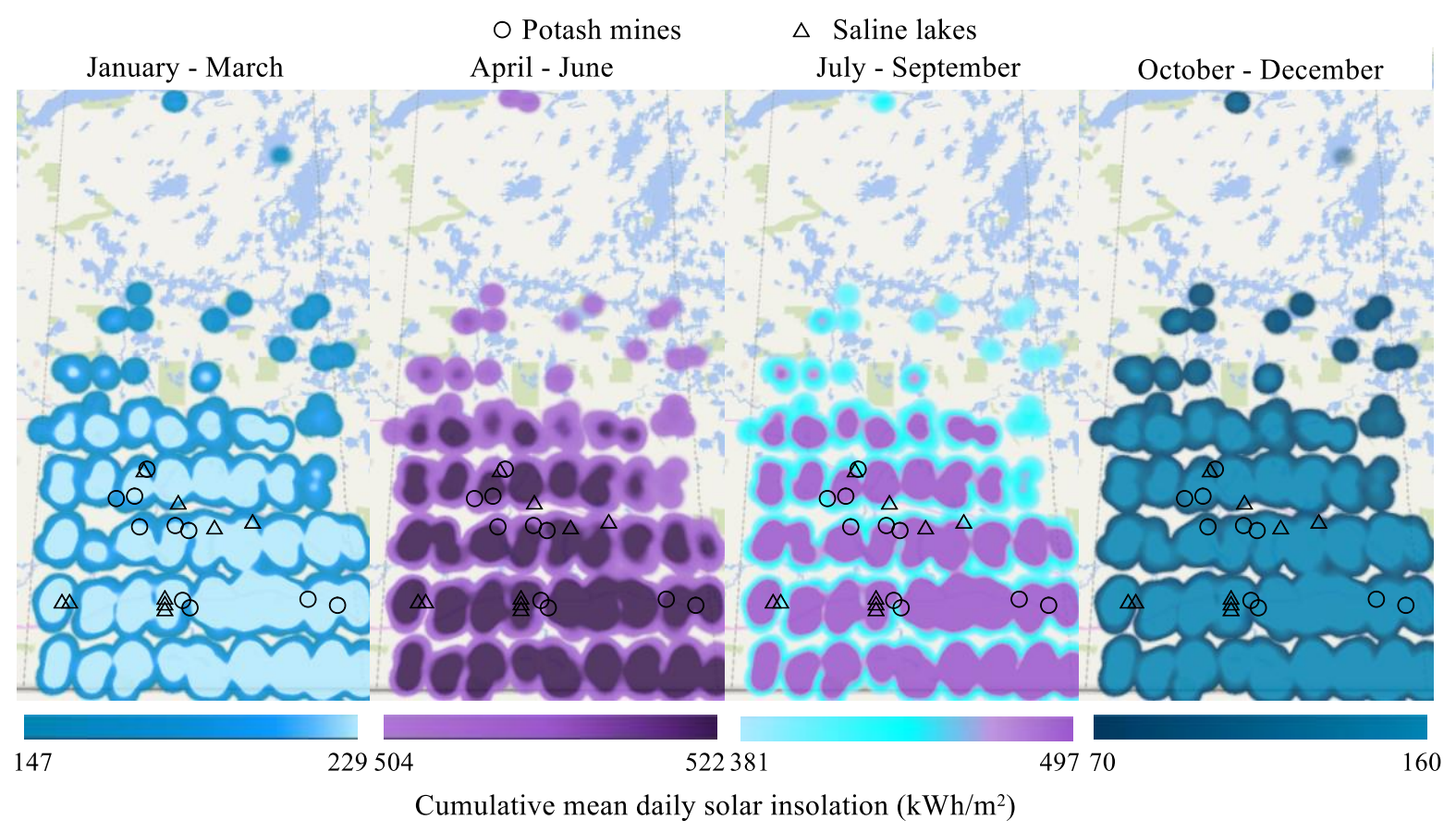

Figure 6. Seasonal solar insolation maps of Saskatchewan along with saline water bodies (Data from National Resources Canada, 2018)
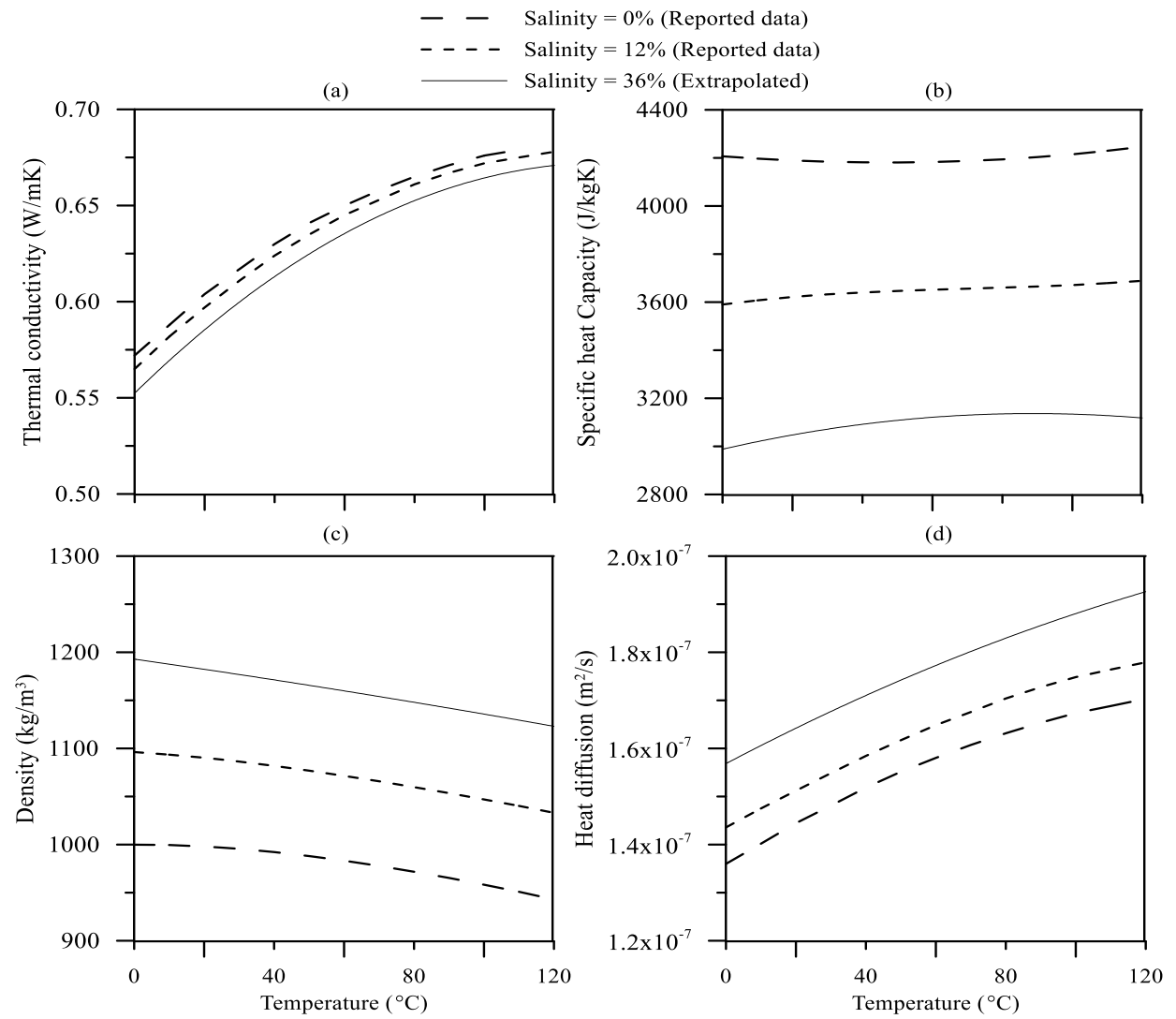

Figure 7. Variation of thermophysical properties with temperature for water with varying salinity 


\section{Conceptual Modeling}

\subsection{Factors Affecting Heat Transfer in SGSP}

Figure 7 gives the variation of thermophysical properties of saline waters with respect to temperature from $0^{\circ}$ to $120^{\circ}$ : (a) thermal conductivity $(k, \mathrm{~W} / \mathrm{m} \mathrm{K})$; (b) specific heat capacity $\left(C_{p}, \mathrm{~J} / \mathrm{kg} \mathrm{K}\right),(\mathrm{c})$ density $\left(\rho, \mathrm{kg} / \mathrm{m}^{3}\right)$; and (d) coefficient of heat diffusion $\left(\alpha, \mathrm{m}^{2} / \mathrm{s}\right)$. The reported data for $0 \%$ to $12 \%$ salinity (Mostafa et al., 2010; Nayar et al., 2016) were used to extrapolate the thermophysical properties for $36 \%$ water salinity (corresponding to concentration of potash tailings). The figure indicates that thermal conductivity increases with temperature raise but decreases with an increase in salinity; the opposite is true for density. Similarly, specific heat capacity slightly increases with temperature and is inversely correlated with salinity. The coefficient of heat diffusion was calculated according to the following expression (Bird et al., 2006):

$\alpha=k /\left(\rho C_{p}\right)$

The above equation means that the coefficient of heat diffusion is directly proportional to thermal conductivity and inversely proportional to specific heat capacity and density. The corresponding polynomial fits for the above-mentioned properties depend on temperature $\left(T,{ }^{\circ} \mathrm{C}\right)$, as given below:

$k=-7 \times 10^{-6} T^{2}+0.002 T+0.6$

$C_{p}=-320 \times 10^{-6} T^{2}+5.211 T+2480$

$\rho=-100 \times 10^{-6} T^{2}-0.596 T+1190$

When water is heated by solar radiation, the energy is transferred to increase the rates of rotational, vibrational, and translational motions. In freshwater, heat is conducted through water molecules forming polymer-like chains by connecting up to eight molecules. Some of these chains are disrupted in saline waters due to the presence of ions such as $\mathrm{Na}^{+}$and $\mathrm{Cl}^{-}$thereby forming a mixture of linked water molecules and free water molecules. This is why thermal conductivity (ability to transfer heat) is maximum for freshwater through the chains and decreases with increasing salt concentration (Talley et al., 2011). In contrast, the specific heat capacity (amount of heat needed to raise the temperature of $1 \mathrm{~kg}$ mass by $1{ }^{\circ} \mathrm{C}$ ) decreases with increasing salt concentration because the relative number of free water molecules in a concentrated solution is higher (more disruptions of the chains) than that in freshwater. This means that the presence of hydrogen bonds creating the water molecule chains are reduced and less energy is required to heat salt water (Brini et al., 2017). Furthermore, the density of salt water is affected by the molecular weight of a solute which increases with an increase in brine concentration (Dincer and Rosen, 2011).

Figure 7 confirms previous observations (Wei, 2015) for the investigated ranges, that is, salinity dependent fluctuations in specific heat capacity $(3000 \sim 4200 \mathrm{~J} / \mathrm{kg} \mathrm{K})$ and density $\left(1000 \sim 1200 \mathrm{~kg} / \mathrm{m}^{3}\right)$ are higher than those in the thermal condu- ctivity $(0.55 \sim 0.675 \mathrm{~W} / \mathrm{mK})$. Consequently, the coefficient of heat diffusion increases with an increase in salt concentration and temperature.

\subsection{Heat Diffusion Modeling for SGSP}

Using $t$ for time (s), and $y$ for pond depth (m), a heat diffusion model was developed for SGSP in the LCZ (where the heat is mostly stored, Figure 1) based on the following equation (Bird et al., 2006):

$$
\frac{\partial T}{\partial t}=\alpha \frac{\partial^{2} T}{\partial y^{2}}
$$

The quasi-one dimensional model (length in $\mathrm{x}$-direction $=$ $1 / 10$ length in y-direction) used a $1 \mathrm{~m}$ deep LCZ along with transient heat diffusion coefficients at selected time steps of 1 $5,10,15,20,25$, and 30 days. The Dirichlet boundary condition (corresponding to $36 \%$ water salinity and receiving 180 $\mathrm{kWh} / \mathrm{m}^{2}$ ) was applied at the top and the Neumann boundary condition $(\partial \mathrm{T} / \partial \mathrm{t}=0$ because only $2 \%$ heat is lost $)$ was applied at the bottom. The initial condition was set to $20{ }^{\circ} \mathrm{C}$ corresponding to the average ambient air temperature.

A partial differential equation solver (FlexPDE) was used for simulating heat diffusion. Based on the finite element method, the solver automatically generated an initial triangular mesh for the prescribed geometry. The governing equation along with the thermophysical property functions (given in Figure 7) were used as model inputs. The compiler carried out spatial and temporal refinement of the initial mesh through automatic mesh refinement to reduce the error within the tolerance limit for the selected units. The model output was in the form of temperature $\left({ }^{\circ} \mathrm{C}\right)$ versus pond depth $(\mathrm{m})$ for selected time intervals over one month period.

Table 1 summarizes the specific data of model development using mesh testing. The default setting of the solver pertained to an initial mesh at the densest possible configuration. The optimum initial mesh density was evaluated for $10 \%$, $50 \%$, and $100 \%$ of the default setting. The automatic mesh refinement function achieved convergence (with marginal error) such that the computing time remained constant (10 seconds) for all cases. The $50 \%$ of default setting was found to be the optimum and was used as the initial mesh density for subsequent analysis.

Table 1. Summary of Mesh Tests

\begin{tabular}{lllll}
\hline Initial mesh density & Nodes & Cells & Cycles & Error $\left(\times 10^{-7}\right)$ \\
\hline $10 \%$ of Default & 71 & 28 & 93 & 10.7 \\
$50 \%$ of Default & 74 & 29 & 101 & 9.2 \\
$100 \%$ of Default & 97 & 34 & 97 & 9.4 \\
\hline
\end{tabular}

Figure 8 presents temperature profiles for a $1 \mathrm{~m}$ thick $\mathrm{NCZ}$ in a typical SGSP for potash tailings containment facility. The temperature was found to decrease from a high value at the surface (solar radiation coming from above) to a lower value at the bottom following a curvilinear path that approach the bound- 
aries at right angles. This means that the model captures the cumulative effect of temperature increase that, in turn, affects each of the thermophysical property (Figure 7). When the family of curves is considered as a whole, two sets of temperature increases are observed at the top: a rapid increase in the first 10 days (from 20 to $46{ }^{\circ} \mathrm{C}$ ) and a low increase in the last 20 days (from 46 to $52{ }^{\circ} \mathrm{C}$ ). This is attributed to the diminishing gradient between the surface and the adjacent lower layer (that absorbs the temperature from above) and the effect is carried forward to the next time step. In contrast, the temperature increase was found to be fairly constant $\left(3.5 \pm 0.6{ }^{\circ} \mathrm{C}\right.$ for every 10 day period) at the pond bottom owing to the applied negligible energy loss at that boundary. Finally, the family of curves tend to approach the surface temperature over time even without convection thereby confirming model applicability to SGSP albeit the absolute values of temperature may vary depending on actual field conditions.

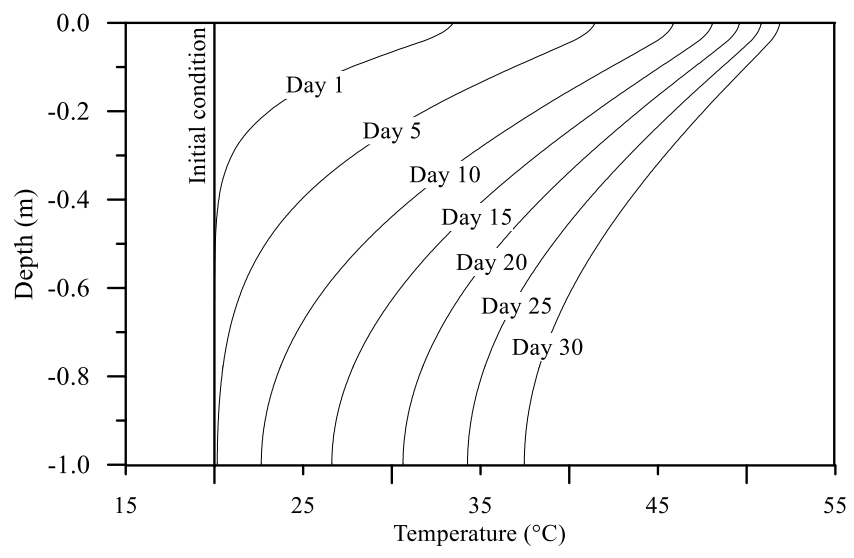

Figure 8. Results of quasi one-dimensional heat diffusion model for SGSP

The conceptual model presented in this paper is at a preliminary stage of development. The following recommendations should be considered for an improved numerical prediction of SGSP: (i) consider convection currents due to heat diffusion within the LCZ; (ii) replicate complex interactions within UCZ, NCZ, and LCZ during heat diffusion; (iii) refine boundary conditions using actual weather data including precipitation, air temperature, wind speed, relative humidity, and daily sunlight duration and amount; (iv) calibrate and verify the modeling results with bench-scale physical models tested under controlled environments; and (v) validate the model by conducting pilot-scale SGSP field testing. To develop a comprehensive understanding of SGSP for Saskatchewan, risk assessments is recommended for aquatic life, ground water, surface flooding, air quality, algal growth, and convective currents.

\section{Summary and Conclusion}

Knowledge of saline gradient solar ponds is critical as a sustainable (cost-effective, environmentally friendly, and socially viable) source of thermal energy. This paper evaluated the feasibility of SGSP as an alternative energy source for
Saskatchewan, Canada. The main achievements of this research were the following: (i) global appraisal of SGSP from theoretical and practical perspectives; (ii) assessment of salinity and climatic criteria for SGSP potential; (iii) clear understanding of heat transfer mechanisms as influenced by thermophysical properties; and (iv) numerical modeling to simulate transient heat diffusion in SGSP. Globally, industrial applications such as mineral production and desalination plants, have SGSP potential provided local climatic conditions are conducive. The main conclusions of the study are given below:

1. Saskatchewan is ideal for SGSP because of a relatively high solar insolation (1100 to $1400 \mathrm{kWh} / \mathrm{m}^{2}$ ). The solar radiation in such systems is captured at the bottom under a vertical salt concentration profile. Based on spatio-temporal correlations, ten potash tailings sites (360 or $36 \%$ salt concentration) and two saline water lakes $(250 \mathrm{~g} / \mathrm{L}$ or $25 \%$ salt concentration) are identified as potentially suitable SGSP candidates.

2. Thermal conductivity was found to increase with temperature raise but decreased with an increase in water salinity $(0.55 \sim 0.675 \mathrm{~W} / \mathrm{m} \mathrm{K})$, the opposite trend was found to be true for density $\left(1000\right.$ to $\left.1200 \mathrm{~kg} / \mathrm{m}^{3}\right)$. Likewise, specific heat capacity was found to slightly increase with temperature and inversely correlated with water salinity (3000 $4200 \mathrm{~J} / \mathrm{kg} \mathrm{K}$ ).

3. The heat diffusion model adequately simulated the temperature distribution profile for a typical SGSP in a potash tailings containment facility. For the investigated month of July (highest solar insolation), the temperatures increased from an initial value of 20 to $52^{\circ} \mathrm{C}$ at top to $37^{\circ} \mathrm{C}$ at bottom. A comprehensive risk assessment of this method is required to protect air, water, soil, and biota at specific sites.

Acknowledgement: The authors would like to acknowledge the University of Regina for providing a computing facility. Thanks to the NASA Langley Research Center (LaRC) POWER project (funded through the NASA Earth Science/Applied Science Program) for providing the solar insolation data.

\section{References}

Abdullah, A.A., Fallatah, H.M., Lindsay, K.A., and Oreijah, M.M. (2017). Measurements of the performance of the experimental saltgradient solar pond at Makkah one year after commissioning. Solar Energy, 150,212-219. https://doi.org/10.1016/j.solener.2017.04.040

Abdullah, A.A., Lindsay, K.A., and AbdelGawad, A.F. (2016). Construction of sustainable heat extraction system and a new scheme of temperature measurement in an experimental solar pond for performance enhancement. Solar Energy, 130, 10-24. https://doi. org/10.1016/j.solener.2016.02.005

Akbarzadeh, A., Andrews, J., and Golding, P. (2005). Solar pond technologies: a review and future directions, in Goswami Y. (EDs), Advances in Solar Energy, Earthscan, London, UK, 233-294.

Aimone-Martin, C.T. and Martell, M.A. (2000). Salinity gradient solar pond technology applied to potash solution mining, in Sanchez M.A., Vergara F., and Castro S.H. (Eds), Environmental Improvements in Mineral Processing and Extractive Metallurgy, University of Concepcion, Chile.

Aizaz, A. and Yousaf, R. (2013). Construction and analysis of a salt 
gradient solar pond for hot water supply. European Scientific Journal, 9, 517-529.

Alcaraz, A., Montala, M., Cortina, J.L., Akbarzadeh, A., Aladjem, C., Farran, A., and Valderrama, C. (2018). Design, construction, operation of the first industrial salinity-gradient solar pond in Europe: An efficiency analysis perspective. Solar Energy, 164,316326. https://doi.org/10.1016/j.solener.2018.02.053

Alcaraz, A., Valderrama, C., Cortina, J.L., Akbarzadeh, A., and Farran, A. (2016). Enhancing the efficiency of solar pond heat extraction by using both lateral and bottom heat exchangers. Solar Energy, 134, 82 - 94. https://doi.org/10.1016/j.solener.2016.04.025

Alenezi, I. (2012). Salinity Gradient Solar Ponds: Theoretical Modelling and Integration with Desalination, $\mathrm{PhD}$ Dissertation, University of Surrey, Surrey, UK.

Assari, M.R., Tabrizi, H.B., Parvar, M., Nejad, A.L., and Beik, A.J.G. (2017). Experiment and optimization of mixed medium effect on small-scale salt gradient solar pond. Solar Energy, 151, 102-109. https://doi.org/10.1016/j.solener.2017.04.042

Bawahab, M., Faqeha, H., Ve, Q.L., Faghih, A., Date, A., and Akbarzadah, A. (2019). Industrial heating application of a Salinity gradient solar pond for salt production. Energy Procedia, 160, 231238. https://doi. org/10.1016/j.egypro.2019.02.141

Bernad, F., Casas S., Gibert, O., Akbarzadeh, A., Cortina, J.L., and Valderrama, C. (2013). Salinity gradient solar pond: Validation and simulation model. Solar Energy, 98, 366-374. https://doi.org/10.10 16/j.solener.2013.10.004

Bird, R.B., Stewart, W.E., and Lightfoot, E.N. (2006). Transport Phenomena, Willey \& Sons, Ltd., USA.

Brini, E., Fennell, C.J., Fernandez-Serra, M., Hribar-Lee, B., Lukšič, M., and Dill, K.A. (2017). How water's properties are encoded in its molecular structure and energies. Chemical Reviews, 117, 1238512414. https://doi.org/10.1021/acs.chemrev.7b00259

Bowman, J. and Sachs, J. (2008). Chemical and physical properties of some saline lakes in Alberta and Saskatchewan. Saline Systems, 4, 1-17. https://doi.org/10.1186/1746-1448-4-3

Busquets, E., Kumar, V., Motta, J., Chacon, R., and, Lu, H. (2012). Thermal analysis and measurement of a solar pond prototype to study the non-convective zone salt gradient stability. Solar Energy, 86:1366-1377. https://doi.org/10.1016/j.solener.2012.01.029

Chinery, G.T. and Siegel, G.R. (1983). Design, construction, and cost of TVA's $4000 \mathrm{~m} 2$ (1- Acre) nonconvecting salt gradient solar pond. ASME Solar Energy Division Fifth Annual Conference, Orlando, Florida, 150-156.

Christiansen, E.A. (1971). Geology of Crater Lake collapse structure in southeastern Saskatchewan. Canadian Journal of Earth Sciences, 8, 1505-1513. https://doi.org/10.1139/e71-140

Dincer, I. and Rosen, M. (2011). Thermal Energy Storage, 2nd Ed, Willey \& Sons, Ltd., USA. https://doi.org/10.1002/9780470970751

Fisher, U., Weinberg, J., and Doron, B. (2010). Integration of solar pond with water desalination. Renewable Energy Systems and Desalina-tion, 2, 418.

French, R.L., Johnson, D.H., Jones, G.F., and Zangrando, F. (1985) Salt-Gradient Solar Ponds: Summary of U.S., Department of Energy Sponsored Research, NASA-CR-174183 19850005997 , NASA, USA.

Fynn, R.P., Short, T.H., Badger, P.C., and Sciarini, M.J. (1981). Monitoring sodium chloride concentrations and density profiles in solar ponds by electrical conductivity and temperature measurement. Annual Meeting American Section of the International Solar, Energy Society, Phoenix, AZ, 3, 386-390.

Ganguly, S., Date, A., and Akbarzadeh, A. (2018). Effectiveness of bottom Insulation of a salinity gradient solar pond. ASME Journal of Solar Energy Engineering, 140, 1-5. https://doi.org/10.1115/1.40 39416

Garman, M.A. and Muntasser, M.A. (2008). Sizing and thermal study of salinity gradient solar ponds connecting with the MED desalination unit. Desalination, 222, 689e95. https://doi.org/10.101 6/j.desal.2007.02.074

Garrido, F., Soto, R., Vergara, J., Walczak, M., Kanehl, P., and Garcia, J. (2012). Solar pond technology for large-scale heat processing in a Chilean mine. Journal of Renewable and Sustainable Energy, 4, 053115. https://doi.org/10.1063/1.4757627

Gasulla, N., Yaakob, Y., Leblanc, J., Akbarzadeh, A., and Cortina, J.L. (2011). Brine clarity maintenance in salinity-gradient solar ponds. Solar Energy, 85, 2894-2902. https://doi.org/10.1016/j.solener.20 11.08.028

Gonzalez, D., Amigo, J., Lorente, S., Bejan, A., and Suarez, F. (2016). Constructal design of salt-gradient solar pond fields. Energy Research, 40, 1428-1446. https://doi.org/10.1002/er.3539

Guerrero, J.S., Pimentel, L.C.G., and Skaggs, T.H. (2013). Analytical solution for the advection-dispersion transport equation in layered media. International Journal of Heat and Mass Transfer, 56, 274282. https://doi.org/10.1016/j.ijheatmasstransfer.2012.09.011

Hammer, U.T. (1986). Saline lake resources of the Canadian Prairies. Canadian Water Resources Journal, 11, 43-57. https://doi.org/10. 4296/cwrj1101043

Hoare, R.A. (1968). Thermal convection in Lake Vanda, Antarctica. Journal of Geophysical Research, 73, 607-612. https://doi.org/10.1 029/JB073i002p00607

Holter, M.E. (1969). The Middle Devonian Evaporite of Saskatchewan. Department of Mineral Resources, Saskatchewan, Canada.

Hull, J.R. (1979). Physics of the Solar Pond. Retrospective Theses and Dissertations, 6608, Iowa State University, Iowa, USA

Hull, J.R. (1982). Calculation of solar pond thermal efficiency with a diffusely reflecting bottom. Solar Energy, 29, 385-389. https://doi. org/10.1016/0038-092X(82)90074-3

International Energy Agency (2014). World Energy Outlook, International Energy Agency, Paris, France.

Ito, M., and Azam, S. (2018). Feasibility of solar energy harvesting from saline water bodies in Saskatchewan, Canada. 3rd International Conference on Integrated Environmental Management for Sustainable Development, Sousse, Tunisia.

Jacobson, M.Z. and Delucchi, M.A. (2011). Providing all global energy with wind, water, and solar power, Part I: Technologies, energy resources, quantities and areas of infrastructure, and materials. Energy Policy, 39, 1154-1169. https://doi.org/10.1016/j.enpol.201 0.11.040

Jones, G.F., Meyer, K.A., Hedstrom, J.C., Dreicer, J.S., and Grimmer, D.P. (1983). Design, construction, and initial operation of the Los Alamos National Laboratory salt-gradient solar pond. ASHE-SED Meeting, Orlando, Florida. https://doi.org/10.2172/5920496

Kalecsinsky, A.V. (1902). Uber die Ungarischen Warmen and Heissen Kochalzseen als Naturlich Warmeaccumulatoren. Ann, Physik, 7, 408. https://doi.org/10.1002/andp.19023120212

Karakilcik, M. and Dincer, I. (2008). Exergetic performance analysis of a solar pond. International Journal of Thermal Sciences, 47, 93 102. https://doi.org/10.1016/j.ijthermalsci.2007.01.012

Khalilian, M. (2017). Energetic performance analysis of solar pond with and without shading effect. Solar Energy, 157, 860-868. https://doi.org/10.1016/j.solener.2017.09.005

Kim, Y.J. (2013). Einstein's random walk and thermal diffusion. Mathmatics.

Landine, P.G. (1993). Weathering and Diagenesis of Saskatchewan Potash Tailings. Ph.D. Dissertation, University of Saskatchewan, Saskatoon, Canada.

Leblanc, J., Akbarzadeh, A., Andrews, J., Lu, H., and Golding, P. (2011). Heat extraction methods from salinity-gradient solar ponds and introduction of a novel system of heat extraction for improved efficiency. Solar Energy, 85, 3103-3142. https://doi.org/10.1016/j. solener.2010.06.005

Lesino, G., and Saravia, L. (1991). Solar ponds in hydrometallurgy and salt production. Solar Energy, 46, 377-382. https://doi.org/10.1016/ 
0038-092X(91)90053-Y

Lin, E.I.H. (1982). A Review of the Salt-gradient Solar Pond Technology. U.S. Department of Energy, USA.

Liu H.S., Jiang L.S., Wu D., and Sun W.C. (2015). Experiment and Simulation Study of a Trapezoidal Salt Gradient Solar Pond. Solar Energy, 122, 1225-1234. https://doi.org/10.1016/j.solener.2015.09. 006

Lu, H., Waltom, J.C., and Swift, A.H.P. (2001). Desalination coupled with salinity-gradient solar ponds. Desalination, 136, 13-23. https:// doi.org/10.1016/S0011-9164(01)00160-6

Lu, H., Swift, A.H.P., Hein, H.D., and Walton, J.C. (2004). Advancements in salinity gradient solar pond technology based on sixteen years of operational experience. Journal of Solar Energy Engineering, 126, 759. https://doi.org/10.1115/1.1667977

Montalà, M., Cortina, J.L., Akbarzadeh, A., and Valderrama, C. (2019). Stability of an industrial salinity gradient solar pond. Solar Energy, 180, 216-225. https://doi.org/10.1016/j.solener.2019.01.017

Mostafa, H., Shargawy, J.H., Lienhard, V.J.H., and Syed, M.Z. (2010). Thermophysical properties of seawater: A review of existing correlation and data. Desalination and Water Treatment, 16, 345380. https://doi.org/10.5004/dwt.2010.1079

NASA Langley Research Center (2018). NASA Prediction of Worldwide Energy Resources. https://power.larc.nasa.gov, accessed 24 October 2018.

Natural Resources Canada (2018). Photovoltaic and solar resource map website, http://www.nrcan.gc.ca/18366.

Nayar, K.G., Shargawy, M.H., Banchik, L.D., and Lienhard, V.J.H. (2016). Thermophysical properties of seawater: A review and new correlations the include pressure dependence. Desalination, 390, 124.https://doi.org/10.1016/j.desal.2016.02.024

Nie, Z., Bu, L., Zheng, M., and Huang, W. (2011). Experimental study of natural brine solar ponds in Tibet. Solar Energy, 85, 1537-1542. https://doi.org/10.1016/j.solener.2011.04.011

Nielsen, C.E. (1988). Salinity-gradient solar ponds, in: Böer K.W. (EDs), Advances in Solar Energy, Springer, Boston, M.A. https://doi.org/ 10.1007/978-1-4613-9945-2_6

Ormat Turbines Ltd. (1981). A Study of the Feasibility of a Solar Salt Pond Generating Facility in the State of California, U.S.A.

Pelland, S., McLenney, D.W., Poissant, Y., Morris, R., Lawrence, K., Campbell, K., and Papadopol, P. (2006). The development of photovoltaic resource maps for Canada. 31st Annual Conference of the Solar Energy Society of Canada (SESCI), Montreal, Canada.

Ruskowitz, J.A., Suarez, F., Tyler, S.W., and Childress, A.E. (2014). Evaporation suppression and solar energy collection in a saltgradient solar pond. Solar Energy, 99, 36-46. https://doi.org/10.10 16/j.solener.2013.10.035

Saleh, A., Qudeiri, J.A., and Al-Nimr, M.A. (2011). Performance investigation of a salt gradient solar pond coupled with desalination facility near the Dead Sea. Energy, 36, 922-931. https://doi.org/ 10.1016/j.energy.2010.12.018

Sarabia, A., Meza, F., and Suarez, F. (2018). Use of fiber-optic distributed temperature sensing to investigate erosion of the nonconvective zone in salt-gradient solar ponds. Solar Energy, 170, 499-509. https://doi.org/10.1016/j.solener.2018.05.078

Sayer, A.H., Al-Hussaini, H., and Campbell, A.N. (2017). Experimental analysis of the temperature and concentration profiles in a salinity gradient solar pond with, and without a liquid cover to suppress evaporation. Solar Energy, 155, 1354-1365. https://doi.org/ 10.101 6/j.solener. 2017.08 .002

Talley, L., Pickard, G., Emery, W., and Swift, J. (2011). Descriptive Physical Oceanography: An Introduction. 6thed, Elsevier Ltd., Amsterdam, Netherlands. https://doi.org/10.1016/B978-0-75064552-2.10001-0

Tallin, J.E., Pufahl, D.E., and Barbour, S.L. (1990). Waste management schemes of potash mines in Saskatchewan. Canadian Journal of Civil Engineering, 17, 528-542. https://doi.org/10.1139/190-061

Tundee, S., Terdtoon, P., Sakulchangsatjatai, P., Singh, R., and Akbarzadeh, A. (2010). Heat extraction from salinity-gradient solar ponds using heat pipe heat exchangers. Solar Energy, 84, 17061716. https://doi.org/10.1016/j.solener.2010.04.010

Wang, L.S., and Ma, P. (2015). Low-grade heat and its definitions of Coefficient-of-Performance (COP). Applied Thermal Engineering, 84, 460-467. https://doi.org/10.1016/j.applthermaleng.2015.03.034

Wei, L. (2015). Impacts of a saline lake and its salinity on local precipitation. Advances in Meteorology, 679634, 1-11. https://doi. org/10.1155/2015/679634

Wittenberg, L.J., and Harris, M.J. (1979). Evaluation of a large nonconvective solar pond. Solar Energy Storage Options, San Antonio, Texas, 1, 193-202.

Zangrando, F. (1991). On the hydrodynamics of salt-gradient solar ponds. Solar Energy, 46, 323-341. https://doi.org/10.1016/0038-09 2X(91)90048-2 